\title{
Travellers' memories: the image of places from literature to blog chatter
}

\author{
Donella Antelmi ${ }^{i}$ \\ Francesca Santulliii \\ Libera Università di Lingue e Comunicazione IULM, Milano (Italia) ${ }^{1}$
}

\begin{abstract}
Starting from the assumption that texts produced in the tourist sector are a form of discourse, the paper focuses on narrative texts and singles out two sub-genres, namely travel literature proper and reports published on tourism websites. The corpus, comprising texts referring to India, is analysed with mainly qualitative methodology. Four aspects are considered in detail: enunciation and the author / reader relationship; the presence of subjective vs objective points of view; the time-space dimension; the exploitation of shared knowledge and stereotypes. The analysis reveals that the two sub-genres share some textual features and, despite their different literary value, both contribute to the construction of an image of the destination which can play a significant role in tourism promotion.
\end{abstract}

Keywords: discourse analysis, the discourse of tourism, travel literature, travel reports, narrative, enunciation, stereotypes

Título: Relatos de viajeros: la imagen de los lugares en la literatura y en los blogs

Resumen: A partir del supuesto de que los textos producidos en el sector turístico constituyen formas discursivas, este artículo se centra en los relatos de experiencias personales de viaje y, en particular, en dos subgéneros: la literatura de viaje y los relatos publicados en las páginas web de turismo. El análisis del corpus, que comprende textos sobre la India, se lleva a cabo mediante metodologías de tipo cualitativo, haciendo especial hincapié en cuatro aspectos: la enunciación y la relación entre autor y lector; la presencia de un punto de vista subjetivo vs objetivo; la dimensión temporal y espacial; la explotación de estereotipos y conocimientos compartidos. El análisis muestra que los dos subgéneros comparten algunos rasgos textuales y, a pesar del diferente valor literario, pueden contribuir a la construcción de la imagen de los destinos, desempeñando un papel significativo en la promoción turística.

Palabras clave: análisis del discurso, discurso del turismo, literatura de viaje, relatos de viaje, narración, enunciación, estereotipos

i E-mail: donella.antelmi@iulm.it

ii E-mail: francesca.santulli@iulm.it 


\section{Introduction}

Marketing in the tourist sector exploits different promotion strategies to stimulate growth in this strategic area, aiming to create a destination brand which can influence choice and increase consumption. Guide books, travel literature, print advertisements and websites are different instruments used to create and enhance a positive image of a place, usually boosting its typical features and distinctive qualities, to generate consumers' interest (Cogno / Dall'Ara, 1997; Giacomarra, 2005).

The importance of this image for the success or failure of tourism management has been recently emphasised by Ferreira Lopes (2011), with a comprehensive review of empirical research on the origin and development of brand image. Ferreira examines a wide choice of previous works on the topic, finding general agreement on the nature of this image, which is treated as a mental representation of the addressee. It is the result of a combination of both concrete elements (the actual characteristics of a place or a personal travel experience) and emotional elements, stemming from indirect experience (which is acquired in different ways, for example through travel literature or advertising campaigns) or simply based on long-entrenched stereotypes, fully integrated in the common knowledge of all people belonging to a certain culture. In other words, in the overall image of a destination there are both experience-based cognitive data and emotional-affective features.

Against this background, this paper will focus on knowledge generated and transmitted through travel narrative, which is a source of indirect experience, and thus contribute to the creation of the brand of a destination. Although these texts obviously reflect the actual travel experience of the author, in this paper they will be considered from the point of view of the addressee, who takes them as a source of information, on the ground of which his/her own image of a place will be constructed.

The texts will be analysed under the linguistic perspective, focusing on the textual structures that are used to give the reader a reliable image of a destination. Furthermore, it will be necessary to take into consideration the distinctive features of different text genres, which determine style choices and - most importantly - the relationship between author and reader. This relationship, in its turn, stimulates the emotional reaction of the addressee and deeply influences the formation of his/her opinions.

\section{Background and aim}

Nowadays the image of a destination is created mainly through advertising and the Internet (the websites of institutions, companies or tour operators, in the first place). In the past, however, before the development of mass tourism, this image was depicted in the realm of literature: diaries, novels and travel reports offered the representation of distant countries and places, and played a crucial role in creating the desire for visiting them.
At the end of the XVII century, book markets in Europe were flooded with a large choice of travel books, which attracted a growing number of readers; according to Brilli (1995: 26), they reflected the principles and philosophical attitudes stemming from the idea of "the Man of Nature", who is always able to come into contact with different ethnic and cultural entities, to comprehend their unusual behaviour and typical customs - even without understanding their language. The practice of the so-called Grand Tour, fostered by the dominating philosophical ideas, was reinforced and found new ways of expression thanks to travel literature.

When, at the end of the XIX century, the tradition of Grand Tour faded away, the importance of travel literature diminished, but it did not completely disappear. A smaller (but still relevant) number of readers has kept buying and enjoying travel books, despite the development and growing importance of guide books (Bonadei / Volli, 2003; Clerici, 2008; D’Agostini, 1987; Panzeri, 2000). Especially when considering remote and exotic places, travellers who want to acquire more comprehensive knowledge, which goes beyond the merely practical information offered by popular travel guides, look for novels, diaries, or even local literature.

Travel literature can be considered a specialised literary genre, with its own readership. It is a vast and heterogeneous field, which includes different sub-genres, ranging from diary to reportage, from travel memories to true novels combining the fictional element with data gathered through the personal experience of the author. Today travel literature is a promising area in tourism communication, as confirmed by the organisation of fairs ${ }^{2}$ and by the existence of special sectors in bookstores or dedicated bookshops.

However, beside travel literature there is a huge number of comments and reports published in specialised websites. As a matter of fact, there are nowadays numerous possibilities of obtaining tourist information on the web; among them, reports published by travellers transformed into amateur writers and reporters represent a more and more frequent opportunity which enjoys growing popularity $^{3}$. In Italy, a few a years ago a popular TV programme launched the habit of narrating personal travel experiences; since then the title of the programme, Turisti per caso ('Tourist by chance'), has been chosen for websites, cartoons and books dedicated to different places and types of tours, all characterised by a form of direct, peer-to-peer communication (Giannitrapani, 2010).

Texts published on websites like Turisti per caso represent a hybrid genre, half-way between the practical informative character of guide books and narrative, with frequent personal, subjective interludes revealing poetic ambitions. In this respect - and despite remarkable differences - they show interesting similarities with more traditional travel literature (Rajotte, 1997).

Both traditional literature and web texts function as a means to create the image of a place. Obviously, web texts have no promotional aim, nor literary ambitions. They of- 
fer a sort of 'impartial' representation of a place, which is examined from the point of view of an observer who has not necessarily gathered historical or cultural information about the destination. In these texts it is therefore easier to single out cultural stereotypes, which are the result of shared knowledge and memories, and can be more easily detected when comparing web narrative with $\mathrm{XX}$ century travel books.

In order to make comparison easier, we have focused on one single destination, India, which is still perceived as a remote and exotic place. In recent years researchers have often focused their attention on India, discussing different literary questions and thus examining the very authors we have chosen to analyse, though from a different perspective (Benvenuti, 2008; D'Aquino, 2006; Dedola, 2006). Our analysis will try to highlight the similarities between web texts and travel books without forgetting the differences. Despite the variety of sub-genres represented and the different literary value of the texts, it is possible to interpret the expression travel narrative in a broad sense, to include texts that show some common distinctive features, to be summarised as follows:

- description of an alien world, which is perceived as unknown: places are seen through the eyes of a traveller who is by no means an expert and does not show a pedagogic attitude; rather, he/she shares with the reader curiosity and willingness to record new impressions;

- comparison with previous knowledge, gathered from guide books or other informative texts: in recent times information contained in traditional guides is often referred to, and sometimes the author shows his/her disagreement, offering alternative practical solutions and, above all, expressing different opinions about places to be visited;

- comparison with one's own previous image of a place. In traditional travel literature the dialogue of the author with his/her own expectations (founded on stereotypes, historical knowledge or literary taste) is often the climax of the narrative: travelling activates emotions and stimulates thought, thus triggering similar reactions in the reader. This form of communication is not completely excluded from web reports, even though they obviously activate different forms of knowledge linked to the present social and cultural situation.

\section{Method}

For this research we have examined a wide choice of Italian websites where travel reports are published, and we have selected the following: http://www.paesionline.it, http://www.viaggiareliberi.it, http://www.marcocavallini. it, http://www.turistipercaso.it; http://www.viaggiatorionline.it.

A corpus of texts has been gathered, which has been analysed also with quantitative methodology, using the Wordsmith Tools suite of programmes. The examples commented on in this paper are taken from this corpus.

Furthermore, we have examined the following travel books: P. P. Pasolini, L'odore dell'India (Parma 1990), G. Gozzano, Verso la cuna del mondo. Lettere dall'India (Milano 1917), E. Emanuelli, Giornale indiano (Milano 1955), G. Manganelli, Esperimento con l'India (Milano 1992), T. Terzani, Un altro giro di giostra (Milano 2004).

From the theoretical point of view this paper adopts a Discourse Analytical perspective, whereby the analysis of linguistic features aims to connect them to the context in which texts are produced and spread, as well as to the subjects involved in communication (Charaudeau / Maingueneau, 2002; Maingueneau, 2005). In this sense, the corpus will be treated as a sample of the discourse of tourism - and more specifically of tourism narratives - in that linguistic choices will be interpreted in light of the context in which the texts considered are generated.

The expression discourse of tourism is meaningful for two reasons. On the one hand, it is reminescent of other similar phrases (political discourse, the discourse of advertising, etc), each of them aiming to single out a sector of communication linked to a special aspect of social life: under this perspective, tourism is the selected area, including a large number of different activities, ranging from economic structures (tour operators, transport facilities, accommodation, etc.) to textual-linguistic production (advertisements, information leaflets, maps, guides, etc.). On the other hand, this expression emphasises the close links between concrete activities and textual production. It is here assumed that texts, far from being the mere expression of a social / political / economic context, actively contribute to the creation of reality itself (Foucault, 1969).

Texts belonging to the discourse of tourism are obviously the product of a social organisation in a well-defined time-place context, but they also contribute to construct their own object; for example, the promotion of a place transforms it into a desirable destination, the recognition of the identity of a region makes it a valuable object for tourism, etc.

Recent research in the field of the discourse of tourism has often focused on the analysis of guide books, which offer a large amount of practical information, but also create an image of the places. Guides describe, offer visual images, select the "highlights" and thus impose what must absolutely be visited: they are also an invitation to travel (Baider Burger / Goutsos, 2004; Ragonese, 2010; Santulli, 2007b; 2010). Destination promotion through the print and the visual media has been another frequent object of research, as it is a strategic marketing tool, crucial to create an attracting and desirable image of the place to be visited (Held, 2004; 2007). Travel literature, on the contrary, has not attracted much interest from the discourse analytical perspective: in this area, texts have been examined for their literary value and their stylistic characters, usually without taking into consideration their specific communicative function and neglecting the mechanisms that lead to the creation of images of the described places that have a special value for tourism.

In this paper some typical features of travel narrative will be taken into consideration, aiming to examine: a) 
the relationship between the participants in the communicative interaction (text-producer and text-receiver), b) features which are constantly exploited in the representation of the destination and thus contribute to the creation of its image for the reader.

As far as the first aspect is concerned, it is obvious that - as in any other form of communication - subjects play their specific role in the interaction: the writer constructs his/her identity and legitimises his/her voice, and at the same time defines the image of the receiver (the 'implied reader', in the literary perspective). The identity of the subjects, their status and roles have important consequences for the pragmatic aim of the communication (information, instruction, invitation, prescription, etc.), enhancing credibility and persuasion.

As for the second aspect, the attention will be focused on linguistic traits more closely linked to the representation of the destination. The destination we have chosen, India, makes it possible to compare texts stemming from a fairly long time span. India has always been perceived as radically different from the Western world, as a consequence of the Eurocentric attitude emphasised in postcolonial criticism. According to Said (1978), this attitude has generated a 'discursive coherence' as regards Eastern countries and cultures, which in its turn largely affected the perception of travellers, writers, and even scholars ${ }^{4}$. As shown by the examined texts, the writers we have considered were influenced by this cultural bias, though they filtered general attitudes through their personal sensibility $^{5}$. The shared opinions about India are also reflected in popular forms of behaviour: for example, in the second half of the XX century the 'spiritual adventure' in India was very attracting for Europeans.

A discussion of post-colonial culture lies however outside the scope of this presentation. Under the discourse analytical perspective adopted here, the comparison between the two groups of texts merely emphasises how stereotypes about India are not limited to the XX century phase, but still survive in contemporary web narrative, which - despite the radically different global context - has a similar impact on its audience, creating and at the same time spreading a mythical image of the Indian world.

The discussion is articulated into four sections.

In the first, the relation between author and reader will be considered, emphasising the textual elements functional to defining the position of both enunciator and enunciatee.

The second will focus on the status of the writer / traveller, who is at the same time narrator and protagonist of the story. This particular situation has important consequences for the representation of the outside world, emphasising the subjective dimension of narration, both in literary and in web texts. In this respect, the realistic description of the places combines with personal impressions and inner emotions, which make these stories different from the objective report typical of guide books.

A third distinctive element in travel reports is how the space-time dimension is managed. Differently from guide books, which adopt a space-oriented presentation and offer a wide choice of maps, travel reports develop in time, thus implying a different fruition of the text itself and a different approach to travelling.

Finally, the attention will be focused on those elements in description (including denominations and comparisons) which refer - albeit implicitly - to shared knowledge, stereotypes and common opinions which contribute to creating, confirming or (more rarely) modifying, the image of a place.

\section{Enunciation: the subjects}

Travel narratives (stories, diaries or reports) are usually contrasted with guide books, from which they differ for their origins, contents and textual structure, representing two different experiences of travelling: the former refer to a past experience of travel, which is described and commented by people who - for the most different reasons, ranging from the dominating fashion of the Grand Tour to scientific interest for exploration, from job to health, etc - have personally travelled and then documented their experience; the latter are focused on the travel "to be done", they are actually based on knowledge acquired thanks to previous experience, but are projected into a future dimension, aiming to show the reader what should be done to grasp the gist of places that are still unknown (Santulli, 2007a).

The two different genres developed in different historical situations (Calvi, 2005²) and, though now co-existing, they seem to imply two different types of addressees: the traveller and the tourist, respectively. This opposition has been described and effectively documented by various authors, who have sometimes used irony to give a more lively representation of the two different types ( $c f r$. Urbain, 1991); recent guide books have also exploited this opposition, assigning different values to the two (Moirand, 2004), so that it has been transformed into a topos of tourism communication.

From a discursive point of view it is important to consider that these two characters, the traveller and the tourist, do not actually correspond to real people: rather, they are fictive subjects created in the textual dimension; they are delineated thanks to the adoption of different forms of enunciation, through which the author gives voice to his/her subjectivity and, at the same time, constructs the identity of his/her ideal addressee ${ }^{6}$.

In a guide book there is no enunciator, or, more precisely, the enunciating entity does not materialise in the text in the first person, but reveals its presence through the adoption of impersonal forms (for example, in Italian, si va) or imperatives (turn right, look at, etc). It addresses a non-expert reader, who is imagined to be hasty and looks for practical information as well as suggestions concerning what should absolutely be seen (KerbratOrecchioni, 2004). The stereotype is so strong that some guides, choosing an alternative dimension, explicitly describe a different situation; Routard, for example, opens 
its Italian version with a significant welcome:

Benvenuti nel mondo delle guide Routard. Se le avete scelte non siete turisti per caso. Preferite definirvi viaggiatori o giramondo? (Le guide Routard. Parigi. 1998: 3) [Welcome in the Routard World. If you have chosen Routard travel books you are not a tourist by chance. Do you consider yourself a traveller or a globetrotter ? $]^{7}$.

In travel narrative, on the contrary, the enunciator is present and talks in the first person, taking full responsibility for the text. The identity of the addressee is strongly conditioned by the very choice of the literary genre, and generates a peer-to-peer relation: the ideal reader is not described, but sometimes addressed, and is constructed in the image of the writer, as a traveller who shares the same idea of travelling and is more interested in experiencing a different reality rather than visiting monuments. Both for the writer and the reader, unusual destinations stimulate desire for new discoveries:

E' bello passeggiare tra queste rovine soprattutto perché in giro di turisti stranieri ce ne sono pochi, visto che la meta è fuori dalle rotte classiche del giro in Rajasthan, i visitatori sono quasi tutti indiani di cui la maggior parte sono bambini, che ogni volta che ci incontrano non perdono l'occasione di salutarci con i loro amichevoli "HALLO" (C) [I like walking among these ruins, above all as there are few foreign tourists, as this place lies outside the usual Rajasthan routes; here the large majority of visitors are Indian, most of them children, who are very friendly and say " Hallo » whenever they meet us].

Travelling is a way of experiencing a new life:

L'India offre veramente un'esperienza a $360^{\circ}$, in cui può succederti di tutto e in cui non ci si annoia mai spendendo veramente pochissimi soldi (C) [India offers a global experience, anything can happen and you never get bored, spending little money].

The style of enunciation is confidential and full of empathy, thus creating a sort of dialogue between writer and reader. The use of first person, singular or plural, emphasises the dialogic dimension, which is further reinforced by frequent forms of address to the reader, conveying different pieces of advice, or explicit suggestions:

Consiglio ai prossimi viaggiatori di prendere in considerazione di effettuare acquisti nella capitale indiana (C) [I suggest future travellers to consider the possiblity of shopping in the Indian capital city].

Io vi sconsiglio di rivolgervi a Karni, ci sono altre agenzie che fanno prezzi migliori (C) [I do not suggest to contact Karni, as there are other agencies offering better conditions].

When narratives refer to one and the same destina- tion, a polyphonic effect is generated, with the construction of a sort of "collective knowledge", made of objective description and practical information on the one side, and, on the other, of subjective and personal emotions. Thanks to this contract of communication, an identity is projected for the reader that sets him/her apart from the stereotyped tourist implied by guide books and acquires some features typical of the traveller. The reader has the same competence as the writer and is encouraged, thanks to these qualities, to live the same experience.

However, the reader of travel literature is by no means obliged to become a traveller in his/her turn; in travel stories and novels the reader can limit him/herself to participating and sharing a representation of reality and, on the basis of a non-prescriptive peer-to-peer relationship, can rely on the image of the place constructed in the text to form his/her own interpretation of it, and of travelling itself.

When compared with the rigid asymmetrical relationship imposed by guide books, the intimate dialogue which is typical of travel literature as well as the peer-to-peer relation implied by web narrative generates a different attitude in the receiver, who experiences the image of a destination as a form of shared heritage, outside the logic of market and profit usually pervading the tourist sector: in other words, this image - far from being construed as an artificial reproduction - is perceived as an authentic picture.

\section{Objective vs subjective dimension}

Travel narratives create and at the same time reflect a community of peers, where the author, who actually travelled, shares his/her experience with the reader, trying to reproduce a realistic image of the visited places, avoiding expert criticism as well as overt didactic attitudes.

All travel literature reveals a difficulty in combining the objective, "scientific" component typical of a rigorous description with the inevitable subjective impression dominating first-person story-telling. According to Rajotte (1998), travel narrative is a metaphorical re-writing and re-reading, as transforming visible space into words requires the author to adopt a certain point of view, and implies a similarly subjective interpretation by the receiver.

The autobiographic component is inevitable both in travel literature and in web narrative. In the former, the author adopts a more intimate and personal tone:

Sono le prime ore della mia presenza in India, e io non so dominare la bestia assetata chiusa dentro di me, come in una gabbia (Pasolini, 9) [I am at the beginning of my Indian experience, and I cannot tame the thirsty beast inside myself, as if in a cage].

While communicating his/her experience, the author may transform his/her first-person narrative into the report of timeless events, thus giving voice to universal feelings: 
[...] Ogni volta che in India si lascia qualche persona, si ha l'impressione di lasciare un moribondo che sta per annegare in mezzo ai rottami di un naufragio $(\mathrm{Pa}-$ solini, 80) [In India, whenever you leave a person, who have the impression of leaving a dying person who is on the verge of drowning in a shipwreck].

Any potentially objective form of experience is always filtered through the perception of the individual:

Le cose mi colpivano ancora con violenza inaudita: cariche di interrogativi, e, come dire, di potenza espressiva (Pasolini, 81). [Things hit me with incredible violence, loaded with questions and, I would say, with a full charge of expressivity].

As a matter of fact, this subjective approach is typical of literary texts (Rajotte, 2000), in which the author is in the foreground, while places remain in the background: the first and foremost example of this attitude in Italian literature is the Divina Commedia.

Despite the lack of literary images, reality in web narratives is also full of subjectivity. Descriptions take into consideration "non-conventional" elements, avoiding those objects that are generally present in guide books (as museums, temples, palaces, etc.); rather, they focus on unusual, picturesque aspects of the landscape and local life, trying to reproduce the impression of the traveller:

Fra Jaipur e Agra ci fermiamo a visitare il Tempio di Balaji, un'esperienza incredibile!!! siamo gli unici turisti in coda fra centinaia di indiani per entrare nel Tempio. [...] appena entrati assistiamo a delle scene che rimarranno per sempre impresse nella nostra memoria... (C) [Between Japur and Agra we stop to visit the Temple of Balaji. An incredible experience !!! There are no other tourists in the queque of hundreds of Indians who wait to enter the Temple. [...] when we are inside we witness unforgettable scenes ...].

In the texts, there are typical features that mark the adoption of a subjective point of view. Colours are described, the time of the day and the light conditions are mentioned to recreate the precise atmosphere of a landscape or a monument; comparisons are exploited to suggest emotions experienced during the visit:

Passiamo due ore fantastiche: prima con il sole che tramonta sul lago e dopo con il buio che cala su Pushkar accompagnato dalle preghiere dei fedeli e dai lumini che galleggiano sull'acqua, insomma veramente un'esperienza fantastica... (C) [We spend two delightful hours there: the sun sets into the lake and it gets dark in Pushkar, while people pray and candles float on the water, a truly fantastic experience]

Thus, the reader is presented with an image of the place filtered through the emotions of the writer, which make it richer and more spectacular. This, in turn, stimulates the emotional reaction of the reader, who is captured and develops a new desire for travelling.

\section{The dimensions of space and time}

Travel narrative displays another interesting aspect which makes it different from guide books, i.e. the way of describing and managing space. Travel guides typically organise space along a linear dimension, offering a predetermined and ordered sequence reproduced in verbal texts as well as through graphic and typographic strategies. The real world, which obviously is a continuum, is transformed into a series of discrete elements: this result is obtained through a process of selection, cognitively separating what must be visited from what does not even deserve to be mentioned, while typographic elements (fonts, bold or italic types, stars, etc.) are exploited to move some elements to the forefront, almost "extracting" them from the continuous space pattern. This obviously emphasises the instructional function of guides, which offer readers pre-determined itineraries and hierarchically ordered objects.

In narrative, space is no longer segmented, it re-acquires continuity thanks to the actual experience of the story-teller who crosses it. The movement from one place to the next is the object of a description, which may be more or less effective, but is always centred on the experience of the traveller. Even when (as it frequently happens with web texts) a narrative presents a sequence of "stop-offs", thus showing a closer similarity with guides, the reader does not get the impression of jumping from one place to the next, as the idea of distance is reproduced mentioning the time spent in travelling.

The diary is often organised along time lines (first day, second day, etc.). Space is a distance to cover, marked by the time taken to reach the different places; as a consequence, the means of transport are closely described, while details are given concerning the local people met on the road, the quality and cost of the food eaten, etc. Travelling generates memories, which are reproduced, taking into account important as well as trivial events:

Il giorno dopo partiamo per Mandawa, entrando nel Rajasthan incontriamo pacifici villaggi e splendide haveli, diciamo un "museo all'aperto...". [...] Un altro giorno e ci dirigiamo a Bikaner, sulla strada regaliamo biro e magliette a piccoli scolari in divisa, visitiamo il famoso tempio dei topi [...]. All'alba si parte per la città d'oro, Jaisalmer, un posto magico sito nel deserto dei Thar (C) [The next day we leave for Mandawa ; in Rajasthan we see peaceful villages and wonderful haveli, a sort of " oper-air museum " [...]. Another day we go to Bikaner, on the way we give ballpoint pens and t-shirts to young boys wearing school-uniforms, we visit the famous temple of the mice [...]. At dawn we leave for the golden city, Jaisalmer, a magic place in the desert of the Thar]. 
The itinerary, typical of a guide book which jumps from one stop-off to the next, is replaced with a multidimensional map, which includes concrete aspects (roads, transports, landscape) as well as the dimension of contact with the local culture. This physical and emotional territory lying in-between makes the perception of distance more acute, and gives the visited places an aura of remoteness both in space and time.

Distance, with all the difficulties implied in crossing remote places, was a relevant aspect in travelling in the past, accurately recorded in XIX-century novels and diaries. Nowadays, air travel has virtually cancelled, or at least drastically reduced distance, but in travel narrative it is taken back to the fore and given new importance. The idea of a vast territory makes places more remote - physically and emotionally - far from domestic life and habits, thus generating a feeling of being "somewhere else": the destination is constructed as a real but remote place, lying outside the realm of ordinary experience. In other words, the so-called Disneyland effect typical of organised tours (from home to Bombay and backwards) is cancelled, while a dimension of movement and evolution dominates the narrative, with emotional and even spiritual components.

This personal and intimate aspect combines with further ideological elements. The link between time and space is a way to emphasise the importance of slow travelling, in sharp contrast with bite-and-go tours which represent the most frequent offer on the tourism market. Slowness is in tune with a more metaphysical concept of travelling, in which diversity is appreciated in all its different dimensions, as it occupies space and develops in time, and thus enables the traveller to perceive, beyond the delights of exotic beauty, minute aspects of reality usually neglected in hasty travelling, which are able to stimulate thought and self-analysis.

The emphasis on the actual movement of travelling is parallel to the lack of extensive description of monuments or historical sites. Curiously, those sites which are celebrated in conventional guide books and presented as the highlights of a tour are given little importance, and the traveller is satisfied with a few stereotyped expressions:

La città [Agra] è meravigliosa (C) [The city [Agra] is wonderful].

Mi accingo a visitare Agra con il bel mausoleo di Sikandra (C) [I am going to visit Agra with the beautiful Sikandra mausoleum].

La visita è molto interessante e il palazzo [di Udaipur] è veramente molto bello $(\mathrm{C})$ [The visit is very interesting and the palace [in Udaipur] is really beautiful].

In literary texts, when the narrator is speechless in front of a landscape or a work of art, he/she resorts to comparisons or quotations; for less educated story-tellers there is nothing else but actual silence: it is useless to repeat what can be found in hundreds of guide books or to describe what can be easily and comfortably seen in photos or films.

Therefore, descriptions are scanty, with one single exception: the perception and verbal reproduction of colours. The synthetic descriptions of places always mention colours, namely white, red, yellow:

Ancora non conoscevo i colori e gli odori di Bombay (Emanuelli, 1001) [Then I did not know the colours and the smells of Bombay yet].

L'immensa rada di Bombay, non paralizzata dall'inesorabile riposo festivo, offre tutta la policromia grandiosa (Gozzano, 631) [The immense bay of Bombay, which is not paralised by the inesorable rest of festive days, displays all its spectacular polychromy].

Si profila l'isola di Elefanta, tutta verde, e dopo l'isola la fascia fulva della terra ferma coronata dalla catena dei Gati: il Bor-Ghat, una muraglia eccelsa di basalto sanguigno (Gozzano, 633). [The island of Elefanta looms ahead. Beyond its green profile, the tawny stripe of the mainland crowned by the Gati chain: BorGhat, a wonderful wall of blood-red basalt]

The presence of colour is so pervasive that, even when there is no three-dimensional description, reading generates a chromatic perception of reality, which is always bright, even in the poorest and most tragic conditions. Again, a subjective perspective is substituted for an objective description of the outside world.

\section{Stereotyped images of a place}

In the analysis of the texts presented in the previous paragraphs, we have focused on how different subjects are expressed (the author, the addressee, the travel experience). In this section the attention shifts on cognitive elements which combine with the former to generate the representation of a place.

As noted above, in narrative texts the voice of the author is strongly perceivable, and this implies that the object of the narrative (or the place) is presented under a subjective perspective, which reflects personal knowledge and convictions of the narrator. However, these are often part of a shared doxa, common-sense assumptions typical of a certain cultural context, or, in Paveau's terms, prédiscours (Paveau, 2006). Even more objective representations are in fact the expression of a rational interpretation of reality, a sort of a fortiori representation which stems from previous processes of understanding, strongly influenced by clichés and cultural stereotypes which impose a pre-determined view of the outside world.

From this perspective, pre-discourse is made up of a set of shared beliefs present in memories and implicit in behaviour, both at an individual and a collective level. In this realm, we find both the categories of perception which precede verbal expression, studied by philosophers, 
and the more trivial data belonging to a common-sense representation of reality, self-evident things that do not need to be discussed.

However, in the context of travel narrative it seems more appropriate to adopt an individual point of view, and consider that pre-discourse coincides with the encyclopaedic knowledge of the author, which stems from personal experience and culture, but is thought to be shared with other people. In travel literature above all, this knowledge - acquired before starting to travel - contributes to increase the enjoyment of the experience itself. A good knowledge of the history of places is one of the reasons why they should be visited, and makes them more interesting and fascinating. While travelling, these historical memories play a crucial role, but are also mixed blessings, as implied in the words of Chateaubriand: "Les souvenirs historiques entrent pour beaucoup dans le plaisir ou dans le déplaisir du voyageur" (Chateaubriand, 1968: 66).

Individual memories can also belong to a common heritage, and for this reason they are understood by other people. They emerge in the texts as similes, forms of address, stock metaphors:

...la città si abbassa rapidamente [...] e se ne gode come si gode di Napoli dall'altura di Posillipo (Gozzano, 638) [The town declines rapidly [...] you can enjoy it as you enjoy Naples from Posillipo hill].

In questa Arcadia [scil. Goa] almeno un neo è chiaramente visibile: i cani (Manganelli, 1240) [In this Archadia [Goa] there is at least a visible fault: the dogs].

As noted by Margarito (2004) some clichés spread and are perpetuated independently of their national origin at least in the European context - and become evident in the choice of certain comparisons or dead metaphors. Therefore, there are numerous passages in which the new is compared with other well-known places and times, memories are activated through metaphors or denominations which create categories thanks to the so-called cliché d'appelation (Margarito, 2004: 126), as in the following examples:

Ancora ai margini di questa grande porta simbolica, altre figure da stampa europea del seicento (Pasolini, 11) [Still around this big symbolic door, high figures in the style of European XVII century printings].

[Goa] è la Roma dell'Oriente (Manganelli, 1241) [[Goa] is the Eastern Rome].

[Goa] è la via Condotti dei tramonti tropicali (Manganelli, 1240) [ [Goa] is the via Condotti of tropical sunsets].

Ecco l'Esplanade[...] E' la passeggiata, il Bois de Boulogne di Bombay (Gozzano, 637). [Here is the Esplanade [...]. It is the Bois of Boulogne of Bombay].

Though these traits of pre-discourse are rather stable in time, discourse memory can include new clichés. Both comparisons and other forms of quotation of pre-discur- sive elements testify of the cultural level of the writer, but they also reflect the social attitudes typical of a certain historical period and contribute to closing the gap between writer and reader:

Arriviamo a Puskar, per visitare il tempio di brahma, questa città ha perso un po' del suo fascino mistico, diventando una località un po' hippy, ci sono molti stranieri che ricordano i figli dei fiori, che si recano in questa cittadina per fare meditazione e ritrovarsi... (C) [We reach Puskar, to visit the temple of Brahma, this city has lost some of its mystic attraction, it has become a rather hippy place, there are many foreigners who remind of the sons of the flowers, who come to this little town to meet and meditate...].

L'India mi ha sempre evocato vecchi racconti Salgariani di primi novecento di tigri mangia uomini, marajha e palazzi d'oro zecchino, vecchi santoni incantatori di serpenti (C) [India always reminded me of old stories by Salgari dating back to the early XX century, tigers which eat men, marajhas and golden palaces, old gurus, snake-charmers].

Il mio driver è uno di quei classici personaggi indiani perfettamente adatto ad impersonare un ruolo nel film "Il nome della rosa" (C) [My driver [English in the text] is one of those typically Indian guys, who would be perfect as a character in the film " The name of the rose "].

Tower of Silence: il nome shelleyano mi prometteva non quel cilindro imbiancato a calce... (Gozzano, 638). [Tower of Silence: the Shelleyan name did not promise that whitewashed cylinder].

Besides these forms of presentation of reality based on pre-discourse, there are other textual strategies which are used to give the description of a place, to define it in ways that are consistent with well-established stereotypes. The creation of such a typified image of a place can be obtained through explicit textual elements, as for example definition, but it can also be the result of implicit structures, through the attribution of qualities or the transformation of the place into an agent producing sensations and emotions (Magri-Morgues, 2010).

An example of such an explicit strategy is the use of the structure India/Indians is/are + predicate, which makes it possible to define India through the attribution of a typical quality, which is often a stereotype.

As definitions create a new reality, which becomes part of the cognitive heritage of the reader and influences - for bad or for good - the image of a destination, their cognitive effect is that of enhancing some aspects of reality which would otherwise remain unobserved ( $c f r$. Perelman / Olbrechts-Tyteca, 1958). In some cases the narrator uses definitions that superficially echo well-accepted concepts (as, for example, India is poor / dirty, etc.) ${ }^{8}$ :

L'India è tra i paesi più a buon mercato del mondo (C) [India is one of the cheapest countries in the world]. 
Chi AMA l'India lo sa: non si sa esattamente perché la si ama. E' sporca, è povera, è...(Terzani, 153) [Those who love India know it: you do not know why you love it. It is dirty, it is poor...].

Questo mondo [...] non è accidentalmente sporco: lo è in modo essenziale, costante, pacato (Manganelli, 1236) [This world [...] is not accidently dirty : it is essentially, constantly, quietly dirty].

E questo il mendicante indiano sapeva, come sapeva che l'indiano non è sensibile, non è disgustabile, non si annoia, e non conosce sensi di colpa (Manganelli, 1235) [And the Indian beggar knew that, and he knew that Indians are not sensitive, cannot be disgusted, do not get bored, and have no concept of blame].

Other examples show an effort to destroy stereotypes and change the images offered by mass tourism, but also in these cases the creation of an image of the place is pursued - even though from an alternative point of view - as is characteristic of this type of discourse:

L'India è veramente un mondo a parte (C) [India is a world of its own].

50 minuti di inutile conversazione! Ah... L'India è anche questo!! (C) [50 minutes of useless conversation! This belongs to India].

A quantitative analysis of the corpus, however, shows that this type of definition is actually rather uncommon; computerised queries reveal that qualities are usually attributed using different enunciative schemes.

One of them is the sequence: predicate + of + India/Indians, which makes the reader infer that India/Indians are/have + predicate. The image thus constructed is presented as necessarily true, since the feature expressed in the predicate is taken as an inherent quality of the place, and for this reason likely to go unchallenged:

Bastano pochi secondi per farmi tornare alla mente la guida spericolata dei drivers indiani, i sorpassi ed i continui colpi di clacson (C) [A few seconds are enough to make me think of the dangerous way of driving of Indian drivers [English in the text], the takeovers, and the repeated honking].

Assenza di indicazioni in inglese, guida folle degli indiani, stato delle strade indecente (C) [Lack of indications in English, the crazy driving of Indians, roads in terrible conditions].

... tra mille colori e profumi, deliziosa la gentilezza e la cordialità degli indiani (C) [... among thousands of colours and smells, the deliciuos gentleness and cordiality of Indians].

La dolcezza degli indiani [...] è uno stato d'animo con equilibrio instabile (Emanuelli, 1008) [The sweetness of Indians is an unstable-balanced mood].

Finally, the toponym occurs in locative expressions which define India as a different place, where the un- thinkable can occur, thus emphasising distance, sense of otherness and, above all, uniqueness:

In quale altro paese, a parte l'India, la gente non chiede niente per farsi fotografare, anzi si mette in posa? (C) [In which other country but India is it possible to photograph people for nothing, they even pose ?].

In conclusione, se come dicono tutti gli Indiani "In India tutto è possibile" non so se da noi possiamo dire lo stesso (C) [In conclusion, if as all Indian say " In India everything is possible", I do not know if we can say the same of ourselves].

Non avevo ancora finito il mio pensiero che, come spesso succede in India, mi trattengo a conversare con due ragazzi indiani arrivati da poco (C) [I haven't formulated my thought yet, and, as it often happens in India, I stop to chat with two Indian boys who have just arrived].

In India il tempo non è sentito come una linea retta, ma circolare... [...] in India si pensano altri pensieri (Terzani, 153) [In India time is not perceived as a line, rather as a circle [...] In India different thoughts are conceived].

This presentation of India as distant and different does not exclude emotional proximity, which is expressed through a personification of the place, transformed into a living creature that influences the mood of the writer, as in the following examples:

Che bella quest'India che mi mette subito a mio agio con i sorrisi disinteressati della gente (C) [How beautiful is this India which immediately makes me feel at ease, with its smiling people].

L'India ti fa sentire semplicemente umano (Terzani, 155) [India makes you simply feel human].

The examples show that the same stereotypes occur in different texts (poverty, kindness, reckless driving, etc) and contribute to the creation of an image of the place. One can wonder if they originate from personal experience or, rather, reflect previously acquired knowledge.

The construction of this stereotyped image can be the result of the proliferation of descriptions themselves, as confirmed by reports of travels across Italy in the XIX century. The authors used to warn their readers against the danger of robberies, disease, even guides (the cicero$n e)$, to the point that Dumas, after having safely visited Italy himself, stated: "On nous a volé nos voleurs" ("we have been robbed of our robbers' Dumas, 1843: 291). Brilli (2003: 15) considers the image of Italy transmitted in travel books a "cultural lie", while the XIX-century traveller aimed to confirm it during his/her actual visit of the country. Today, the same attitude can be seen in travellers to India, who look for what had been "promised" in the books they read before leaving. For example, they usually try to visit some famous monuments in the best conditions: Taj Mahal must be seen at dawn (as suggested 
in guide books), and this is accepted by all travellers, even those who show alternative and independent behaviour.

On the other hand, comparison of reality with travel books read before leaving is often disappointing:

Prima di arrivarci avevo letto tutto quello che si poteva ricavare da ampie e minuziose guide; non c'è niente da fare: è impossibile leggere alcunché e trovare che il luogo che dobbiamo visitare è più o meno simile. Non ci si orizzonta nemmeno. Certo, nelle guide mancano gli odori e i colori. (Manganelli, 1239) [Before getting there I had read all I could in voluminous and accurate travel books; there is nothing you can do: it is impossible to read something and then find that the place we visit is similar to what we have read. You cannot make head or tail of it. Surely, in travel books there are no smells nor colours].

Finally, the place-name itself can be transformed into a stereotype: syntactically, this implies that it is used as a predicate. While in the structures examined above (India is / the X of India) India is (part of) the subject, which is attributed a distinctive quality, this strategy implies that the designative power of the name is enriched with stereotyped semantic values and thus used as a formula to evoke its attributes, with a rhetoric process of antonomasia. The attributes, in their turn, can determine what India is as well as what it is not:

Goa non è India, dicono gli esperti. Il paesaggio è dolce, piccoli villaggi, chiese... (C) [Goa is not India, experts say. The landscape is sweet, small villages, churches...].

Non dirò che Bombay, questa città di denti e di asfalto, non abbia in sé nulla di indiano (Manganelli, 1238) [I cannot say that Bombay, this city of teeth and asphalt, has nothing Indian in itself.]

In this special use, a proper name goes beyond its referential meaning, and becomes a symbol. This way of using the name generates a sort of halo effect, so that India implies a whole universe of knowledge and images, marking the uniqueness of the place and, in terms of marketing, becoming a true brand, which is consequently exploited in advertisements and communication in general ${ }^{9}$.

\section{Final remarks}

In tourism the image of a destination - both under the subjective perspective, as individual perception of the place, and as the outcome of a deliberate marketing process aiming to create a brand - results from a combination of objective features with cognitive and emotional elements. The creation and evolution of the image of a place is enhanced through different media and text genres: among them, guide books and advertisements have been more frequently considered from the point of view of communication sciences. Besides guides and advertisements, however, other genres, old and new, contribute to the construction of a destination's image, making an interesting object of analysis, while possibly offering opportunities for brand development.

In particular, travel books can no longer be considered as the mere by-product of an aristocratic trend, functioning as a mirror of the habits of an ancient past. Actually, they have always been a means to raise curiosities and disseminate knowledge, which in turn contributed to the popularity of the Grand Tour model. But, three centuries later, in the digital era, new forms of interactions are possible thanks to the Internet, and dedicated websites develop to allow the publication of reports and diaries which can have similar effects: they attract, generate wish for travelling, and contribute to creating an image of the places it is worth visiting.

In both cases (travel books and web reports) the texts are not produced with a clear and deliberate promotional aim. However, the fact that a place is given value in the texts makes it attracting, and transforms it into a potential tourist resort - beyond the intentions of the authors, who are soon willing to complain for the excessive market-oriented promotion of the visited destinations. This "value-adding" process is particularly evident in the case of exotic destinations (as the one considered for this research), which become interesting for tourism because they have attracted writers who can tell their stories and offer first-hand information (Brucculeri, 2010).

Novels and diaries from the XIX and XX centuries share some important features with the self-made publications available on the web. Despite this, it is quite obvious that the authors of the former had a different approach to writing, emphasising the expression of personal feelings and creating a special relationship with the reader. In both cases, however, shared knowledge and stereotypes are largely exploited but combined with emotional elements which make these texts profoundly different from guide books.

When compared with guides, which are characterised by an impersonal and objective presentation, travel narrative implies a different "reading contract" with the addressees, which requires more participation and makes the relationship more authentic. The constant presence of a subject who describes his/her own experience is a crucial element for persuasion, as the addressee is lead to identify with the "implied reader" of the text, who (according to the dichotomy mentioned above) is not a tourist to be "guided", but rather a traveller capable of living the same experience as the writer's.

Furthermore, travel narrative published on the web creates a community of producers/receivers who can transform the discourse of tourism into a peer-to-peer interaction, thus going beyond the logic of one-way information flow, which is typical of guides (which aim to "faire connaître [...], fair voir [...], (dé)conseiller de faire qualque chose"; cfr. Moirand, 2004). The effectiveness of this new form of communication lies in the polyphonic character of a discourse in which anyone can play both the role of read- 
er and writer. All participants are true or potential travellers, while the 'democratic' exchange of information is a form of guarantee for its reliability. In websites, however, it is also possible to read texts of more influential writers, who combine freshness and spontaneity with prestige deriving from their experience. Experience and prestige are exactly the qualities which characterise travel books written by novelists or journalists, who are able to exploit well-known stereotypes, easily recognisable by their readers (Antelmi, 2010).

To sum up, if we acknowledge that contemporary web narrative and past travel literature share a sort of 'family likeness', we must admit that the former play an important role in stimulating imagination and generating images of potential tourist destinations, which can no longer be neglected in the development of marketing policies and actual promotion strategies.

\section{References}

Antelmi, Donella

2010 "Viaggiatori e testi: identità discorsive". In Giannitrapani, A. / Ragonese, R. (Eds.), Guide turistiche. Spazi, percorsi, sguardi, E/C Serie Speciale, IV (6): 3542.

Baider, Fabienne / Burger, Marcel / Goutsos, Dionysis (Eds.)

2004 La communication touristique. Approches discursives de l'identité et de l'alterité. Paris: L'Harmattan.

Benvenuti, Giuliana

2008 Il viaggiatore come autore. L'India nella letteratura italiana del Novecento. Bologna: Il Mulino.

Bonadei, Rossana and Volli, Ugo (Eds.)

2003 Lo sguardo del turista e il racconto dei luoghi. Milano: Franco Angeli.

Brilli, Attilio

1995 Quando viaggiare era un'arte. Il romanzo del Grand Tour. Bologna: Il Mulino.

Brilli, Attilio

2003 Un paese di romantici briganti. Gli italiani nell'immaginario del Grand Tour. Bologna: Il Mulino.

Brucculeri, Maria Claudia

2010 "Retoriche dell'antiturismo". In Giannitrapani, A. I Ragonese, R. (Eds.), Guide turistiche. Spazi, percorsi, sguardi, E/C Serie Speciale, IV (6): 103-116.

Calvi, Maria Vittoria

$2005^{2}$ Il linguaggio spagnolo del turismo. Viareggio-Lucca: Baroni.

Castaldo, Barbara

2011 "Uno spaccato fantasmagorico da epoche lontane dalla nostra: Pasolini in India".Between, 1, 2, (http:// ojs.unica.it/index.php/between/article/view/306; 22.2.2012)

Clerici, Luca (Ed.)

2008 Scrittori italiani di viaggio. Milano: Mondadori.

Charaudeau, Patrick / Maingueneau, Dominique (Eds)

2002 Dictionnaire d'Analyse du Discours. Paris: Éditions du Seuil.

Chateaubriand, François-René

1968 Voyage en Italie. Genève: Librairie Droz, (publié d'abord en 1827 dans les OEuvres complètes, chez Ladvocat).

Cogno, Enrico / Dall'Ara, Giancarlo

1997 Comunicazione e tecnica pubblicitaria nel turismo. Milano: FrancoAngeli.

D’Agostini, Maria Enrica (Ed.)

1987 La letteratura di viaggio: storia e prospettive di un genere letterario. Milano: Guerini.

D'Aquino, Alida

2006 L'io e l'altro. Il viaggio in India da Gozzano a Terzani. Roma: Avagliano.

Dedola, Rossana

2006 La valigia delle Indie e altri bagagli. Racconti di viaggiatori illustri. Milano: Bruno Mondadori.

Dumas, Alexandre

1843 Le Corricolo. Paris: Dolin.

Ferreira Lopes, Sérgio Dominique

2011 "Destination image: Origins, Developments and Implications". Pasos, 9 (2): 305-315.

Foucault, Michel

1969 L’Archéologie du Savoir. Paris: Gallimard.

Giacomarra, Mario

2005 Turismo e comunicazione. Strategie di costruzione del prodotto turistico. Palermo: Sellerio.

Giannitrapani, Alice

2010 "Verso una guida transmediale. Turisti per caso". In Giannitrapani, A. / Ragonese, R. (Eds.), Guide turistiche. Spazi, percorsi, sguardi, E/C Serie Speciale, IV (6): 85-98.

Held, Gudrun

2004 "L’annuncio pubblicitario di destinazione. Osservazioni su un tipo di testo multimodale nella stampa odierna”. In D'Achille, P. (Eds), Generi, architetture e forme testuali (pp. 257-277). Firenze: Cesati.

Held, Gudrun

2007 "Spazi, segni e sogni: l'annuncio di destinazione, testo multimodale nella comunicazione turistica". In: Antelmi, D., Held, G. / Santulli, F., Pragmatica della comunicazione turistica (pp. 219-285). Roma: Editori Riuniti.

Kerbrat-Orecchioni, Katherine

2004 "Suivez la guide! Les modalités de l'invitation au voyage dans les guides touristiques: l'exemple de l'ile d'Aphrodite". In Baider F. / Burger, M. / Goutsos D. (Eds.), La communication touristique. Approches discursives de l'identité et de l'altérité / Tourist Communication. Discursive Approach to Identity and Otherness (pp. 133-150). Paris: L'Harmattan.

Magri-Morgues, Véronique

2010 "Construction du stéréotype et modalisation". In Iliescu, M. / Stiller-Runggaldier, H. / Danler, P. (Eds.), Actes du XXV Congrès International de Linguistique et Philologie Romanes, vol. V (pp. 153-162). L’Aja: De Gruyter. 
Maingueneau, Dominique

2005 "L'analyse du discours. Etat de l'art et perspectives ". Marges linguistiques, 9 (http://www.margeslinguistiques.com - 20.10.2008).

Maingueneau, Dominique

2009 Les termes clés de l'analyse du discours. Paris : Editions du Seuil.

Margarito, Maria Grazia

2004 "Quelques configurations de stéréotypes dans les textes touristiques". In Baider F. / Burger, M. / Goutsos D. (Eds.), La communication touristique. Approches discursives de l'identité et de l'altérité / Tourist Communication. Discursive Approach to Identity and Otherness (pp. 117-132). Paris: L'Harmattan.

Moirand, Sophie

2004 "Le même et l'autre dans les guides de voyage au XXIe siècle”. In: Baider F. / Burger, M. / Goutsos D. (Eds.), La communication touristique. Approches discursives de l'identité et de l'altérité / Tourist Communication. Discursive Approach to Identity and Otherness (pp. 151-172). Paris: L'Harmattan.

Panzeri, Fulvio (Ed.)

2000 I luoghi dell'anima. In viaggio con i grandi scrittori. Novara: Interlinea.

Paveau, Marie-Anne

2006 Les prédiscours. Sens, mémoire, cognition. Paris: Presse Sorbonne Nouvelle.

Perelman, Chaïm / Olbrechts-Tyteca, Lucie

1958 Traité de l'argumentation. La nouvelle rhétorique. Paris: Presses Universitaires di France.

Ragonese, Ruggero

2010 "Stabilità e instabilità narrative: spazi e percorsi nelle guide turistiche". In: Giannitrapani, A. / Ragonese, R. (Eds), Guide turistiche. Spazi, percorsi, sguardi, E/C Serie Speciale, IV (6): 51-60.

Rajotte, Pierre

1997 Le récit de voyage, aux frontières du littéraire. Montréal: Éditions Triptyque.

Rajotte, Pierre

1998 "Rendre l'espace lisible : le récit de voyage au XIX siècle". Studies in Canadian Literature, 23 (1). (http://journals.hil.unb.ca/index.php/SCL/article/ view/8276/13948 - 20.10.2011)

Rajotte, Pierre

2000 "Le récit de voyage au XIXe siècle. Une pratique de l'intime", Globe. Revue internationale d'études québécoises, 3 (1): 15-37.

Said, Edward

1978 Orientalism. New York: Pantheon Books.

Santulli, Francesca

2007a "Le parole e i luoghi. Descrizione e racconto". In Antelmi, D. / Held, G. / Santulli, F., Pragmatica della comunicazione turistica (pp. 81-153). Roma: Editori Riuniti.

Santulli, Francesca

$2007 \mathrm{~b}$ "Il discorso procedurale come tratto distintivo della guida turistica: evoluzione diacronica e variazioni sincroniche”. In Garzone, G. / Salvi, R. (Eds), Linguistica, linguaggi specialistici, didattica delle lingue. Studi in onore di Leo Schena (pp. 227-240). Roma: CISU.

Santulli, Francesca

2010 "La guida turistica come genere: tratti costitutivi e realizzazioni testuali”. In Giannitrapani, A. / Ragonese, R. (Eds), Guide turistiche. Spazi, percorsi, sguardi, E/C Serie Speciale, IV (6): 25-34.

Urbain, J.-Didier

1991 L’idiot du voyage, Histoires de touristes. Paris: Plon.

\section{Notes}

1 The authors share responsibility for the general organisation of the paper, choice of approach, corpus selection and analysis of results. However, Donella Antelmi has written the following paragraphs: Introduction, Background and aim, Method, Enunciation: the subjects, Objective vs subjective dimension; Francesca Santulli has written: The dimensions of space and time, Stereotyped images of a place and Final remarks.

2 Among them, the best known in Italy are the following: Festival della Letteratura di viaggio, 4th edition in 2011 (http:// www.festivaletteraturadiviaggio.it/); Festival per la letteratura di viaggio l'Albatros - Città di Palestrina (http://www.premioalbatros.org/); Biennale del libro di viaggio (http://www.librodiviaggio.it/progetto.htm ).

3 A simple query on the Google search engine reveals that the number of sites hosting travel reports is constantly growing.

4 Said actually emphasised the Middle-Eastern situation, but his considerations can easily be applied to a wider area.

5 For example, as noted by Castaldo (2011), Pasolini's interest for primitive cultures and emargination influences his descriptions of India.

6 Within different terminological frameworks, this figure is referred to as co-enunciator, enunciatee, or implied reader (cfr. Maingueneau, 2009).

7 The source of the examples is indicated in the text. For travel books the name of the author is followed by page number, while web texts are marked with C (Corpus). To make language observations clearer, we translated the examples in English as literary as possible.

8 In the examples, the analysed structures are emphasised.

9 Obviously, this cognitive dimension is differently exploited in other types of discourse: for example, outside the realm of tourism, India recalls different sets of ideas, each of them typical of a socio-cultural sector, which are not necessarily connected with those emerging in the discourse of tourism.

$\begin{array}{lr}\text { Recibido: } & 27 / 12 / 2011 \\ \text { Reenviado: } & 24 / 2 / 2012 \\ \text { Aceptado: } & 28 / 2 / 2012\end{array}$

Sometido a evaluación por pares anónimos 